\title{
Taxonomy and Nomenclature of three infraspecific taxa of Cyperus (Cyperaceae)
}

Vadhyaruparambil, Paravoothara, Chendamangalam, Ernakulam District, Kerala - 683512 (Formerly Scientist 'E' \& HoO, Central National Herbarium, Botanical Survey of India, Botanic Garden

P.O., Howrah, West Bengal - 711103, India Corresponding author: prasad_parur@yahoo.com

\section{सायपेरस (सायपेरेसी) के तीन अन्तः जातिय टैक्सा की वर्गिकी}

\section{एवं नामकरण}

वी.पी. प्रसाद

\section{सारांश}

कायलिंगा पॉलिफायला उपजाति बेबिएन्सिस वाड.खान एवं लक्षिमन. को सायपेरस ब्रेविफोलियस (रोटटब.) एंड़ल. एक्स हस्क में स्थानांतरित किया गया है तथा कायलिंगा मेलनोस्पर्मा प्रभेद गुडालूरिएंसिस वाड.खान एवं आर.डी. टौर (इसायपेरस मेलनोर्स्पमस प्रभेद गुडालूरिएंसिस वाड.खान एवं आर.डी. टौर) कोटैम) के रूप में संकुचित किया गया है। इसे सायपेरस मेलनोर्स्पमस (नीस) वाल्क.सुर. एवं कायलिंगा नेमोरेलिस प्रभेद सबनेमोरेलिस वाड.खान एवं सरदेसाई के समानार्थक से हटा कर स्पष्टीकरण के साथ सायपेरस मिंडोरेंसिस (स्टीयूड) ह्यूग के समानार्थक के रूप में प्रतिपादित किया गया है।

\section{Abstract}

Kyllinga polyphylla subsp. babiensis Wad.Khan \& Lakshmin. is transferred to Cyperus brevifolius (Rottb.) Endl. ex Hassk. and reduced to a forma. Kyllinga melanosperma var. gudaluriensis Wad.Khan \& R.D. Taur [三 Cyperus melanospermus var. gudaluriensis (Wad.Khan \& R.D. Taur) Kottaim.] is relegated to a synonym of Cyperus melanospermus (Nees) Valck.Sur. and Kyllinga nemoralis var. subnemoralis Wad.Khan \& Sardesai is treated as a synonym of Cyperus mindorensis (Steud.) Huygh, with justification.

Keywords: Cyperus, Kyllinga, Nomenclature, Synonym, Taxa, Type

\section{INTRODUCTION}

The section Kyllinga (Rottb.) J. Kern of the subgenus Cyperus of Cyperus L. is often treated as a subgenus of Cyperus L. (Kükenthal, 1935-1936) and Kern (1974). But it has been treated as a distinct genus by many cyperologists (Clarke, 1893-1894; Koyama, 1985; Kukkonen, 2001; Dai \& al., 2010). Recently Larridon $\&$ al. $(2013,2014)$ proposed a broad circumscription for the genus Cyperus based on the molecular phylogenetic analysis, wherein the allied genera including Kyllinga were merged with it. The section Kyllinga can be distinguished morphologically by the capitate inflorescence of compressed spikelets with deciduous rachillae, distigmatic styles and laterally compressed achenes with one edge towards the rachilla. Though there are distinct morphological characters to segregate Kyllinga as a distinct genus, it is treated here as a section of the subgenus Cyperus of Cyperus (s.l.), as recognised by Larridon \& al. (2014). 
Clarke (1893) reported six species of Kyllinga from British India, all occurring within the present political boundaries of the country. Karthikeyan \& al. (1989) reported seven species, one subspecies and two varieties. Govindarajalu \& Ramani (1994) described two species and reported one as new to India, thereby making the total number of species in India 10. Subsequently, Wadood Khan (2015) added six new taxa comprising one species, one subspecies and four varieties. So, the total number of taxa reported from India became 19, comprising 11 species, two subspecies and six varieties. Among this, K. odorata Vahl included by Karthikeyan \& al. (1989) is represented in India by its subspecies, namely K. odorata subsp. cylindrica (Nees) T. Koyama [ $\equiv$ Cyperus sesquiflorus (Torr.) Mattf. \& Kük. subsp. cylindricus (Nees) T. Koyama]. Kyllinga pumila Michx. reported by Govindarajalu \& Ramani (1994) is of doubtful distribution in India, as the specimen mentioned by them could not be located in any of the Indian herbaria and not reported by anyone else from India hitherto. In fact, the native distribution range of the species is in Africa, Madagascar, central and eastern USA, and South America. Similarly, K. brevifolia var. leiolepis (Franch. \& Sav.) Karthik. reported by Karthikeyan \& al. (1989) is not from the present political boundaries of India, but Nepal. Apart from this $K$. pluristaminea Govind. \& Ramani and K. eglandulosa Govind. \& Ramani were found to be synonyms of $K$. brevifolia Rottb. [ミCyperus brevifolius (Rottb.) Hassk.] and K. melanosperma Nees [ $\equiv$ Cyperus melanospermus (Nees) Valck.Sur.], respectively (Prasad, 2017), and Kyllinga pseudoalata Wad.Khan \& R.D. Taur was reduced to a synonym of Cyperus tenuifolius (Steud.) Dandy ( $\equiv$ K. tenuifolia Steud.) by Prasad (2021).

Further studies on certain type specimens at CAL revealed that K. polyphylla subsp. babiensis Wad.Khan \& Lakshmin. is a larger form of Cyperus brevifolius (Rottb.) Hassk. ( $\equiv$ Kyllinga brevifolia Rottb.) and hence transferred to the latter with new status as forma. $K$. melanosperma var. gudaluriensis Wad.Khan \& R.D. Taur does not require varietal status as it is described based on minor variations of Cyperus melanospermus (Nees) Valck.Sur. ( $\equiv$ Kyllinga melanosperma Nees) and K. nemoralis var. subnemoralis Wad.Khan \& Sardesai is a minor variant of Cyperus mindorensis (Steud.) Huygh. The correct nomenclature of these taxa is provided here along with original bibliographic citations and information on relevant type specimens. The reasons for proposing the new synonyms are also provided in the notes.
1. Cyperus brevifolius (Rottb.) Hassk. forma babiensis (Wad.Khan \& Lakshmin.) V.P. Prasad, comb. \& stat. nov.

Kyllinga polyphylla Willd. ex Kunth subsp. babiensis Wad.Khan \& Lakshmin. in Wad.Khan, Cyperaceae W. Ghats, W. Coast \& Maharashtra: 273. 2015.

Type: INDIA. Maharashtra: Beed district, Telgaon road, Babi village, 12.5.2009 W. Khan 4798 (Iso: CAL 0000025457!).

(Fig. 1)

Diagnosis: Cyperus brevifolius forma babiensis has close affinity to the typical C. brevifolius. But it differs in exceptionally large size of the plant and in its habitat. In typical C. brevifolius, which grows in open areas, the height of the culm is 5 to $40 \mathrm{~cm}$. But forma baiensis that occurs in shady areas among bushes has culms of 100 to $150 \mathrm{~cm}$ height.

Notes: A detailed study of the type of K. polyphylla subsp. babiensis Wad.Khan \& Lakshmin. revealed that it is a large form of Cyperus brevifolius (Rottb.) Hassk. ( $\equiv K$. brevifolia Rottb.), a variable species. The rhizome is thin and long-creeping, with up to $3.5 \mathrm{~cm}$ long and $1 \mathrm{~mm}$ thick internodes and distantly arranged culms (not approximate); culms narrow (up to $1 \mathrm{~mm}$ thick); leaves up to $2 \mathrm{~mm}$ broad; inflorescence with 3 or 4 involucral bracts; spikelets $2.2-2.5 \mathrm{~mm}$ long, with $c$. $2.2 \mathrm{~mm}$ long glumes; stamen 1 ; achene $c .1 .1 \times 0.7 \mathrm{~mm}$. All these characters (both vegetative and floral) match exactly with Cyperus brevifolius, not Kyllinga polyphylla Willd. ex Kunth [ $\equiv$ Cyperus aromaticus (Ridl.) Mattf. \& Kük.]. The exceptionally long culms or height of the plant (up to $100 \mathrm{~cm}$ in the above-mentioned isotype, and up to $150 \mathrm{~cm}$ in the protologue) is the notable difference from the typical C. brevifolius. It is mentioned in the protologue that all the involucral bracts are erect or 1 or 2 suberect and the lowest one seemingly continuation of the culm, pushing aside the inflorescence (pseudolateral). But in the abovementioned type specimen, the bracts are spreading and the inflorescence not pseudolateral (Fig. 1a \& c). Moreover, the erect bracts and pseudolateral inflorescence are often found in Cyperus brevifolius, but not in Cyperus aromaticus. In C. aromaticus ( $\equiv K$. polyphylla) the rhizome is $2-4 \mathrm{~mm}$ thick, without long internodes and hence the culms closely arranged (approximate); culms stout (2-4 $\mathrm{mm}$ thick); leaves broader (3-4 mm); inflorescence with 7 or 8 involucral bracts; spikelets 3-3.5 mm long, with $2.5-3.5 \mathrm{~mm}$ long glumes; stamens 3 ; achene $1.5-2 \times 0.6-0.7 \mathrm{~mm}$. Hence, it is confirmed that the type of K. polyphylla subsp. 


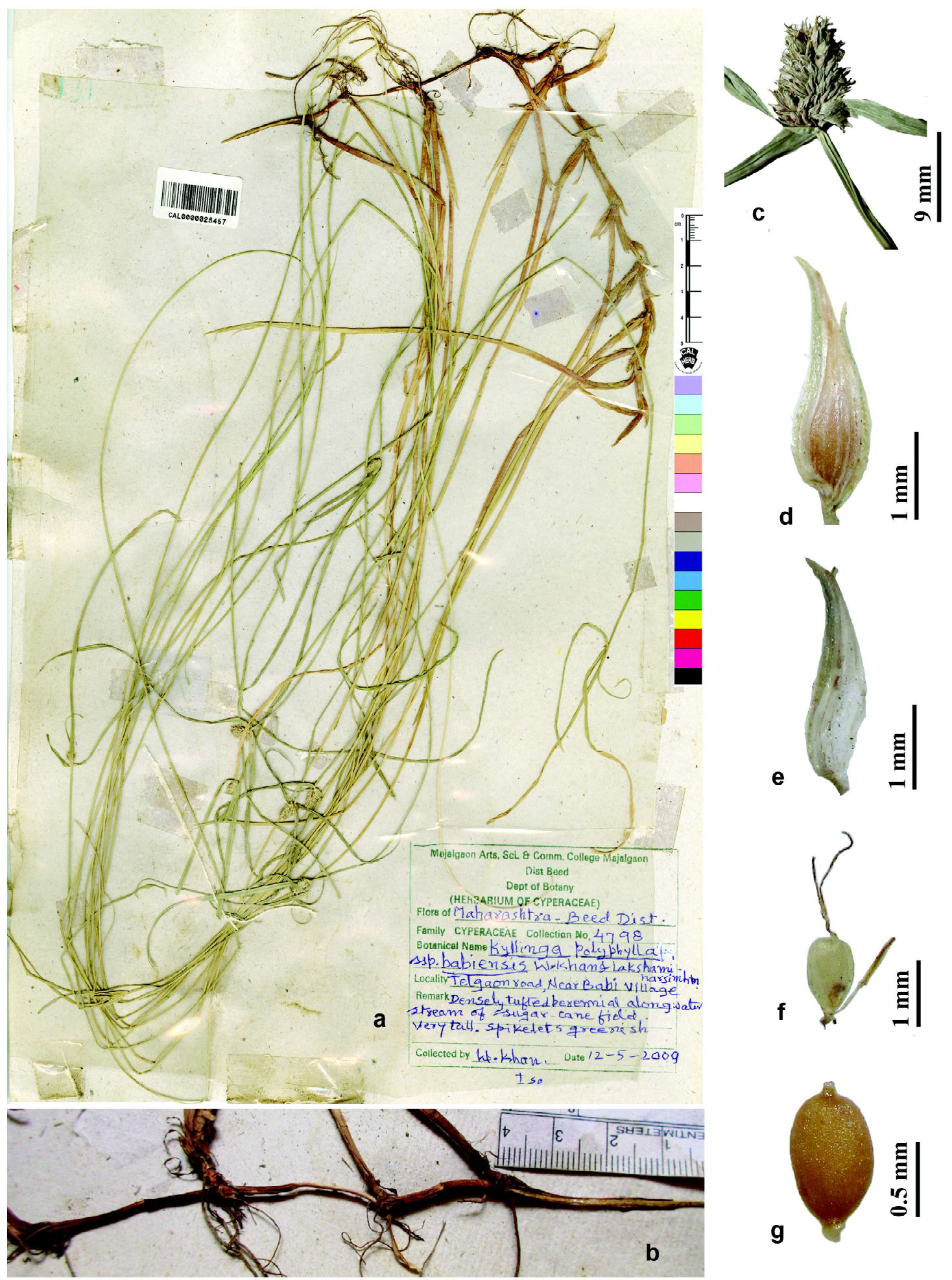

Fig.1. a. Image of Isotype Kyllinga polyphylla Willd. ex Kunth subsp. babiensis Wad.Khan \& Lakshmin.; b. Rhizome with long internodes and distantly arranged culms; c. Inflorescence; d. Spikelet; e. Glume (side view); f. Flower in later stage with stamen, style and immature achene; g. Achene. 
babiensis belongs to Cyperus brevifolius (Rottb.) Hassk. ( $\equiv$ K. brevifolia Rottb.). Therefore, it is transferred to C. brevifolius, but reduced to the rank of forma, considering the exceptionally tall culms or height of the plant.

Cyperus melanospermus (Nees) Valck.Sur., Geslacht Cyperus Mal. Archipel.: 50, t. 2, f. 8. 1898. Kyllinga melanosperma Nees in Wight, Contr. Bot. India: 91. 1834; C.B. Clarke in Hook.f., Fl. Brit. India 6: 588. 1893; Karthik. \& al., Fl. Ind. Enum. Monocot.: 60. 1989.

Type: INDIA. R. Wight 1851 (K [K000308263, image!]) - The annotation by C.B. Clarke says, this is the type on which the species was founded. https://apps.kew.org/ herbcat/getImage.do?imageBarcode=K000308263.

Kyllinga melanosperma Nees var. gudaluriensis Wad.Khan \& R.D. Taur in Wad.Khan, Cyperaceae W. Ghats, W. Coast \& Maharashtra: 269. 2015. Cyperus melanospermus (Nees) Valck.Sur. var. gudaluriensis (Wad.Khan \& R.D. Taur) Kottaim., Int. J. Curr. Res. Biosci. Pl. Biol. 6(10): 38. 2019, syn. nov.

Type: INDIA. Tamil Nadu: On the way from Ooty to Gudallur, 10.11.2003, R.D. Taur \& D.P. Chavan 615 (Holo and Iso: Herbarium of Cyperaceae, Majalgaon College, Majalgaon!).

(Fig. 2)

Notes: The holotype of K. melanosperma var. gudaluriensis Wad.Khan \& R.D. Taur (an incomplete specimen, without underground parts) was studied and confirmed that there is no need to recognise this as a distinct variety. The differences given in the protologue to separate it from typical K. melanosperma [ Cyperus melanospermus (Nees) Valck.Sur.] are 7 or 8-nerved spikelets; nerves not purplish and achenes $c .0 .8 \mathrm{~mm}$ broad. But, in K. melanosperma nerves can be 3 or 4 on each side of the glume, and hence it can be 8 in each glume or on one side of the spikelet, including the 3rd and 4 th glumes covering the achene. Colour of the nerves need not be purplish always, and that cannot be considered as an important character. Achenes can be up to $0.8 \mathrm{~mm}$ broad in typical $K$. melanosperma. It is also written on the type sheet that keel is smooth. But, in the specimen, both smooth and spinulose keels were found on the glumes.

Cyperus mindorensis (Steud.) Huygh, Phytotaxa 166: 39. 2014. Kyllinga mindorensis Steud., Syn. Pl. Glumac. 2: 67.1854.

Type: Philippines, Manillle, Cuming 1558 (P [P00578843, image!]). http://coldb.mnhn.fr/ catalognumber/mnhn/p/p00578843.
Thryocephalon nemorale J.R. Forst. \& G. Forst., Char. Gen. Pl., ed. 2: 129, t. 65. 1776.

Kyllinga nemoralis (J.R. Forst. \& G. Forst.) Dandy ex Hutch. \& Dalziel, Fl. W. Trop. Afr. 2: 487. 1936, non Cyperus nemoralis Cherm. 1921; Karthik. \& al., Fl. Ind. Enum. Monocot.: 60. 1989.

Type: French Polynesia, J.R. Forster \& G. Forster s.n. (Lecto BM [BM000990844, image!]).

Kyllinga monocephala Rottb., Descr. Icon. Rar. Pl.: 13, t. 4, f. 4. 1773, nom. Illeg.; C.B. Clarke in Hook.f., Fl. Brit. India 6: 588.1893.

Kyllinga nemoralis (J.R. Forst. \& G. Forst.) Dandy ex Hutch. \& Dalziel var. subnemoralis Wad.Khan \& Sardesai in Wad.Khan, Cyperaceae W. Ghats, W. Coast \& Maharashtra: 271. 2015, syn. nov.

Type: INDIA, Karnataka: Honavar to Jog falls, 13.10.2004, D.P. Chavan 5375 ([Para: Herbarium of Cyperaceae, Majalgaon College, Majalgaon!). (Fig. 3)

Notes: The paratype of K. nemoralis var. subnemoralis Wad.Khan \& Sardesai was studied and found no considerable differences to treat it as a distinct variety. The characters given in the protologue are either overlapping or minor variations. As per the protologue spikelets are broadly ellipsoid and 1-flowered; glumes muticous or apiculate, with narrow and smooth or nearly smooth wings of the keel, and achenes broadly ellipsoid, $1.5-1.8 \times 0.8-0.9 \mathrm{~mm}$. But, in Cyperus mindorensis shape of the spikelets is variable from ovate to elliptic or even ovate-lanceolate, often 1-flowered and usually 1-fruited. Glumes are generally apiculate or mucronate and the wings on the keel can be minutely to prominently serrulate, and the achene shape vary from oblong to oblong-obovate, or even suborbicular. In the above mentioned paratype sparsely serrulate wings were found on the keel of the glumes and the achenes were found to be oblong-obovate and c. $1.5 \times$ $7.5 \mathrm{~mm}$.

So, it is concluded here that K. nemoralis var. subnemoralis Wad.Khan \& Sardesai was described based on overlapping characters and minor variations, hence treated here as a synonym of Cyperus mindorensis (Steud.) Huygh.

\section{ACKNOWLEDGEMENTS}

The author is grateful to the Director, Botanical Survey of India (BSI), Kolkata and the Head of Office, CAL, BSI, Howrah, for the facilities. Grateful thanks are also 


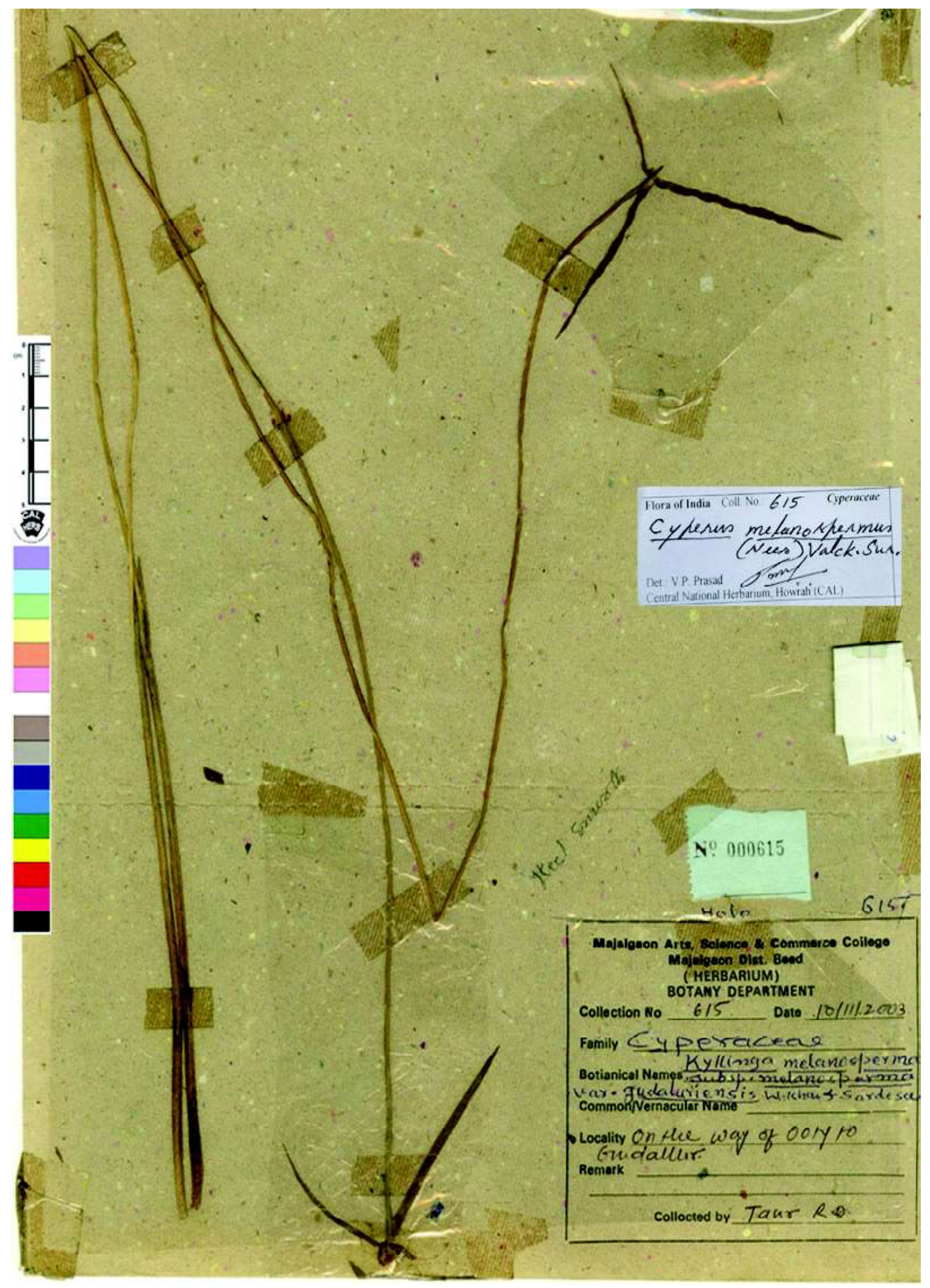

Fig. 2. Holotype of Kyllinga melanosperma Nees var. gudaluriensis Wad.Khan \& R.D. Taur 


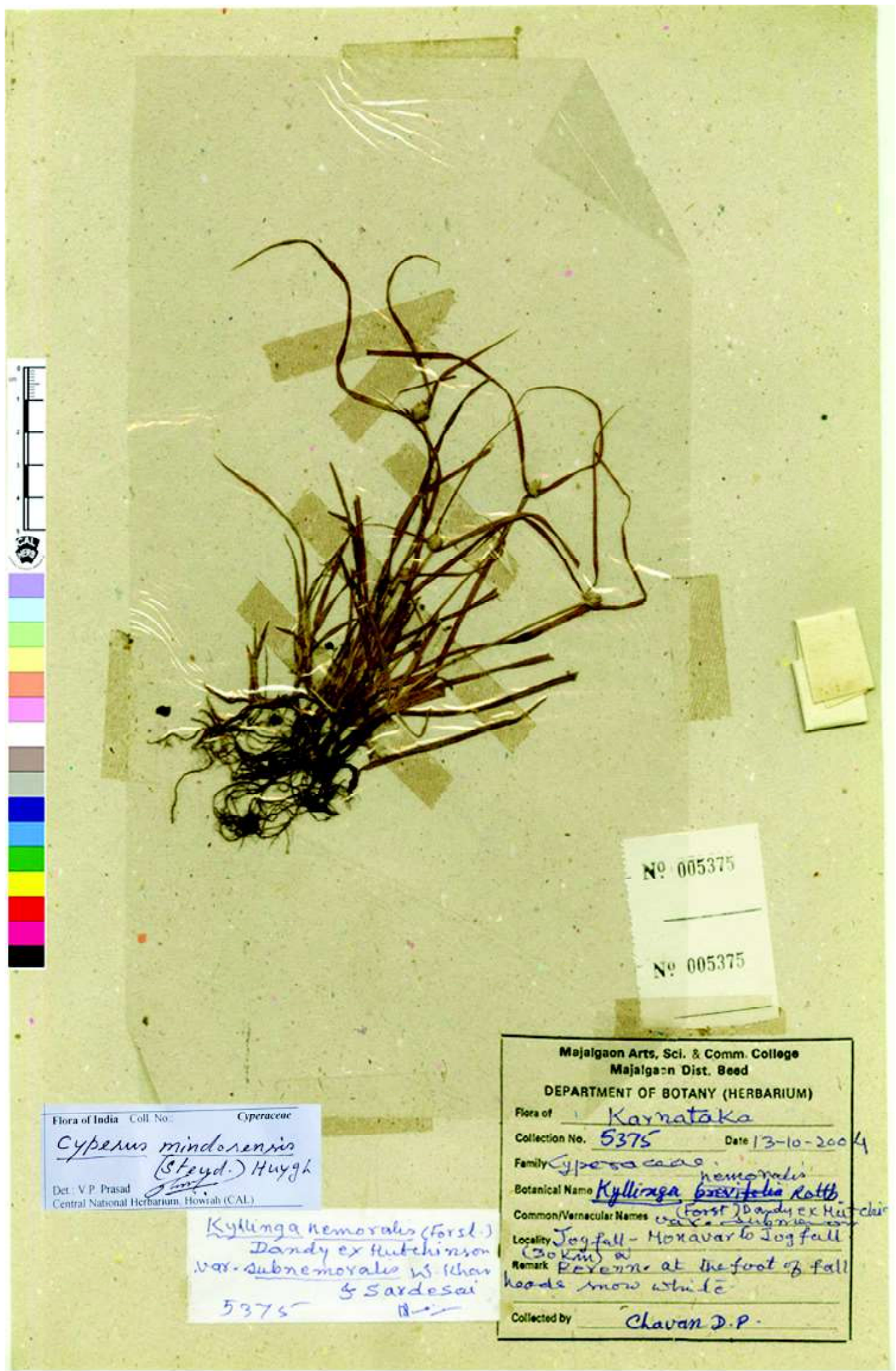

Fig.3. Paratype of Kyllinga nemoralis (J.R. Forst. \& G. Forst.) Dandy ex Hutch. \& Dalziel var. subnemoralis Wad.Khan \& Sardesai 
due to Dr. M.A. Wadood Khan, Retired Professor, Majalgaon Arts, Science \& Commerce College, Beed district, Maharashtra, for providing the type specimens on loan. The Collection Manager, Natural History Museum of Denmark, University of Copenhagen has kindly provided image of the type of Kyllinga brevifolia Rottb. Image of the type of K. melanosperma Nees was accessed from the Herbarium Catalogue Database of Royal Botanic Gardens, Kew. Image of the type of $K$. mindorensis Steud. was accessed from the Collection Database of Muséum national d'Histoire naturelle (MNHN), Paris. Image of the lectotype of Thryocephalon nemorale J.R. Forst. \& G. Forst. was downloaded from the Data Portal of Natural History Museum, London. Dr. W. Arisdason, Scientist 'D', BSI, Coimbatore, has kindly gone through the manuscript and improved its quality. Thanks are also due to my former colleagues at CAL, Howrah, Dr. Avishek Bhattacharjee, Scientist 'C', Dr. Anand Kumar, Botanist, Dr. Gopal Krishna, Botanical Assistant and Mr. Dinesh Sah, Artist, for their help in different ways.

\section{REFERENCES}

CLARKE, C.B. 1893-1894. Cyperaceae. In: Hooker, J.D. (ed.), The Flora of British India. Vol. 6. L. Reeve \& Co., London. pp. 585-748.

DAI, L.K., G.C. TUCKER AND D. SIMPSON 2010. CYPERACEAE. In: Wu, Z. \& Raven, P.H. (eds.), Flora of China. Vol. 23. Science Press, Beijing and Missouri Botanical Garden, St. Louis. pp. 246-249.

GOVINDARAJALU, E. AND RAMANI, K. 1994. Cyperaceae Indiae Australis Precursores: Two new species and one new record in Kyllinga Rottb. and Scanning Electron Microscopic observations. J. Econ. Taxon. Bot. 18(2): 335-343.

KARTHIKEYAN, S., S.K. JAIN, M.P. NAYAR AND SANJAPPA, M. 1989. Florae Indicae Enumeratio: Monocotyledonae. Botanical Survey of India, Kolkata. pp. 60-61.

KERN, J.H. 1974. Cyperaceae. In: Steenis, C.G.G.J. van (ed.), Flora Malesiana. Ser. 1, Vol. 7(3). Noordhoff International Publishing, Leiden. pp. 653-660.
KOYAMA, T. 1985. Cyperaceae. In: Dassanayake, M.D. (ed.). A Revised Handbook to the Flora of Ceylon. Vol. 5. Amerind Publishing Co. Pvt. Ltd., New Delhi. pp. 125-405.

KÜKENTHAL, G. 1935-1936. Cyperaceae - Scirpoideae - Cypereae. In: Engler, H.G.A. (ed.), Das Pflanzenreich: Regni vegetabilis conspectus. IV(20), Heft 101. W. Engelmann, Leipzig. pp. 566-614.

KUKKONEN, I. 2001. In: Ali, S.I. \& Qaiser, M. (eds.), Flora of Pakistan. No. 206 Cyperaceae. University of Karachi, Karachi and Missouri Botanical Garden, St. Louis. pp. 153-159.

LARRIDON, I., K. BAUTERS, M. REYNDERS, W. HUYGH, A.M. MUASYA, D.A. SIMPSON AND P. GOETGHEBEUR 2013. Towards a new classification of the giant paraphyletic genus Cyperus (Cyperaceae): phylogenetic relationships and generic delimitation in C4 Cyperus. Bot. J. Linn. Soc. 172(1): 106-126. https:// doi.org/10.1111/boj.12020

LARRIDON, I., K. BAUTERS, M. REYNDERS, W. HUYGH AND P. GOETGHEBEUR, 2014. Taxonomic changes in C4 Cyperus (Cypereae, Cyperoideae, Cyperaceae): combining the sedge genera Ascolepis, Kyllinga and Pycreus into Cyperus s.l. Phytotaxa 166(1): 33-48. https://doi.org/10.11646/phytotaxa.166.1.2

PRASAD, V.P. 2017. Two new synonyms in the genus Kyllinga (Cyperaceae). Phytotaxonomy 16: 23-25.

PRASAD, V.P. 2021. On the identity and occurrence of Cyperus pseudoalatus and Cyperus richardii (Cyperaceae) in India. Rheedea 31(2): 85-88. https:// dx.doi.org/10.22244/rheedea.2021.31.09

WADOOD KHAN, M.A. 2015. Cyperaceae of Western Ghats, West Coast and Maharashtra. Dattsons, Nagpur. pp. 264-275. 